\title{
SLAG AND ASH CHEMISTRY AFTER HIGH-CALCIUM LIGNITE COMBUSTION IN A PULVERIZED COAL-FIRED POWER PLANT
}

\author{
G. PAPASTERGIOS ${ }^{1}$ \\ J.L. FERNÁNDEZ -TURIEL ${ }^{2}$ \\ A. GEORGAKOPOULOS ${ }^{1^{*}}$ \\ D. GIMENO ${ }^{3}$
}

\author{
${ }^{1}$ Department of Mineralogy-Petrology-Economic Geology \\ School of Geology, Aristotle University of Thessaloniki \\ 54124, Thessaloniki \\ ${ }^{2}$ Consejo Superior de Investigaciones Cientificas (CSIC) \\ Institute of Earth Sciences "Jaume Almera" \\ Barcelona, Spain \\ ${ }^{3}$ Department of Geochemistry \\ Petrology and Geological Exploration \\ University of Barcelona, Spain
}

Received: 20/11/05

Accepted: 29/03/06 *to whom all correspondence should be addressed: e-mail: ageorgak@geo.auth.gr

\begin{abstract}
More than $73 \%$ of the electrical power requirements of Greece are generated in lignite-fired power plants. Greece is the thirteenth largest coal and the fifth largest lignite producer in the world. The lack of domestic high-rank coals makes necessary to use low quality lignite for power generation in Greece. These lignites are characterized by a high water and ash content and a low calorific value. The low quality of such lignites generates important technical and environmental problems during combustion. Slagging and fouling are common inside the power units and affect with particular severity the power plants performance. Slagging deposits take place in the high temperature radiant sections of the boiler, and are usually associated with some degree of melting of the ash. Fouling deposits are produced in the lower temperature convective sections of the boiler, and are generally related to condensation on the low temperature tube surfaces. Problems in boilers associated with ash deposits include modification of the heat transfer in different sections of the furnace, physical distortion of metal pieces due to the weight of the deposit, clogging of burners, and corrosion and erosion of metal walls. Feed lignite always carries more than $20 \%$ of inorganic matter, and its mineralogy and chemistry are originally related to geological factors. Five representative samples were collected from the inner surfaces of Unit 1 of the Agios Dimitrios Power Plant, Northern Greece, reflecting the main types of ash deposits occurring in the combustion facility. The chemistry of these high-calcium ash deposits has been investigated. Moreover, a fly ash and a bottom ash samples were taken and analyzed in order to investigate their possible impact on the environment after land-filling. All samples were digested by using 2.5 $\mathrm{ml} \mathrm{HNO}_{3}, 5 \mathrm{ml} \mathrm{HF}$ and $2.5 \mathrm{ml} \mathrm{HClO}_{4}$ (1:2:1). Sixty element concentrations were determined in all samples by inductively coupled plasma-mass spectrometry (ICP-MS) and inductively coupled plasma - optical emission spectrometry (ICP-OES). Calcium is the most abundant element in all samples due to the dominance of calcium phases. The chemical composition of the bottom ash, fly ash, slag and fouling deposits, is mainly influenced by the chemical composition of the feed lignite and the co-excavated sterile materials, which are marly limestones containing, on average, $93 \%$ of calcite.
\end{abstract}

KEYWORDS: lignite, power plant, slagging, fouling, bottom ash, fly ash, environment.

\section{INTRODUCTION}

The contribution of lignite to the total electric power generation of Greece is nearly up to $73 \%$. Lignite is the most common type of coal in Greece, occurring in more than 60 sedimentary basins. The main coal mining areas in Greece are the Lignite Centre of Western Macedonia 
(LCWM) in Northern Greece and the Megalopolis Lignite Centre (MLC) in the Peloponese, Southern Greece. The lignites exploited in these opencast mines are used to generate electricity in the power plants of Liptol (43 MW), Amynteon (600 MW), Ptolemais (620 MW), Kardia (1200 MW) and Agios Dimitrios (1595 MW) in the LCWM, and Megalopolis A (550 $\mathrm{MW}$ ) and Megalopolis B (300 MW) in the MLC. These plants consume approximately 73 million tons of lignite per year and produce nearly 13 million tons of fly ash per year. Agios Dimitrios is a typical steam generating Power Plant, the biggest lignite fired Power Plant of Greece, having a total installed capacity of $1595 \mathrm{MW}$ in five thermal units [1-6].

Greek lignites are characterized by low calorific value and high water and ash contents. This lignite is one of the poorest fossil fuel used worldwide. Feed lignite carries at least $20 \%$ of inorganic matter $(\mathrm{db})$, and its mineralogy and chemistry are originally related to geological factors. The quality of the recoverable lignite, from an economical and environmental point of view, is related to the properties of the organic and the inorganic matter, as well as the nature of the thin intermediate sterile layers, which are co-excavated with lignite. The usage of such lignites causes important technical problems during combustion inside the boilers of the power units [3-8]. Ash deposition phenomena as slagging and fouling frequently occur. These phenomena depend highly on ash chemistry and mineralogy and affect severely the power plant performance. Slagging deposits take place in the high temperature radiant sections of the boiler while fouling deposits are produced in the lower temperature convective sections, and are generally related to condensation on the low temperature tube surfaces. Some of the most common problems caused by slagging and fouling deposits in the boilers are modification of the heat transfer in different sections of the furnace, physical distortion of metal pieces due to the weight of the deposit, clogging of burners, and corrosion and erosion of metal walls. The present study investigates the chemical composition and behavior of the slagging and fouling deposits that occur inside Unit 1 of Agios Dimitrios power plant as well as of a bottom ash and a fly ash sampled from the same unit.

\section{MATERIALS AND METHODS}

Five of the seven samples examined in the present study were collected from the inner surfaces of Thermal Unit 1 of the Agios Dimitrios Power plant, representing the main types of slagging and fouling deposits occurring in the combustion facility. The remaining two samples were a bottom ash and a fly ash sample, collected in the hoppers of the electrostatic precipitators, of the same Unit (Fig. 1).

A split of $0.1 \mathrm{~g}$ of each sample was placed into teflon beakers which had formerly been

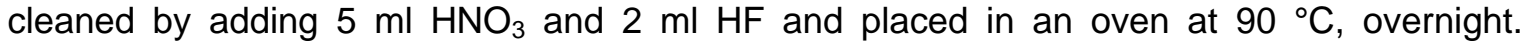
Afterwards, all samples except for sample GP-7 (bottom ash), were digested with $10 \mathrm{ml}$ of $\mathrm{HNO}_{3}: \mathrm{HClO}_{4}: \mathrm{HF}(2.5: 2.5: 5, \mathrm{v} / \mathrm{v})$. The solutions were heated up on a hot plate until the evaporation of $\mathrm{HNO}_{3}$ and $\mathrm{HF}$. Then, $2.5 \mathrm{ml} \mathrm{HNO}_{3}$ and $5 \mathrm{ml} \mathrm{HF}$ were added and the samples were inserted in an oven for 2 hours. The procedure was repeated three times. Finally, the samples were evaporated to almost complete dryness. All samples were inserted in $100 \mathrm{ml}$ volumetric flasks and were made up to volume with milliQ $\mathrm{H}_{2} \mathrm{O}\left(1 \% \mathrm{HNO}_{3}\right)$ achieving this way a direct compatibility with the instruments used for the analysis (ICP-OES and ICP-MS).

Sample GP-7 (bottom ash) was treated with $2.5 \mathrm{ml} \mathrm{HNO}_{3}+2.5 \mathrm{ml}$ milliQ $\mathrm{H}_{2} \mathrm{O}$ for about 2 hours inside an oven before following the previously described digestion procedure. To evaporate the acid, the solution was placed on a hot plate. Then, $2 \mathrm{ml} \mathrm{HNO}_{3}$ and $2 \mathrm{ml} \mathrm{H}_{2} \mathrm{O}_{2}$ $(0.5+0.5+0.5+0.5)$ were added. The solution was, once again, placed, covered, on a hot plate, and left to evaporate. The complete dissolution of the unburned lignite was achieved by adding $5 \mathrm{ml} \mathrm{HF}$, and $2 \mathrm{ml} \mathrm{HNO}_{3}$ in an oven for $18 \mathrm{~h}$ at $90{ }^{\circ} \mathrm{C}$. Generally, in the bottom ash samples from the power plants of Northern Greece, the unburned lignite content varies between $38-48 \%$ [9]. 


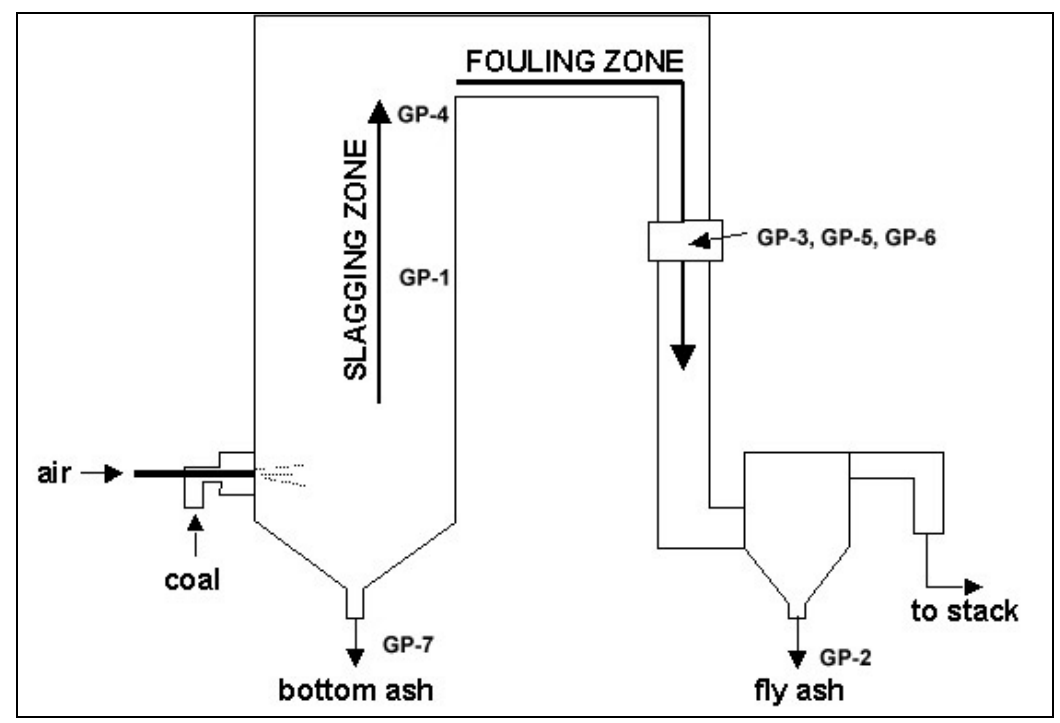

Figure 1. Samples location inside Unit 1 of Agios Dimitrios power plant (modified after Fernández-Turiel et al., 2004).

Ten major (Al, P, Ca, Mg, K, Fe, Na, Si, S, Cl), and fifty trace elements ( $\mathrm{Li}, \mathrm{Be}, \mathrm{B}, \mathrm{Ti}, \mathrm{V}, \mathrm{Cr}$, $\mathrm{Mn}, \mathrm{Co}, \mathrm{Ni}, \mathrm{Cu}, \mathrm{Zn}, \mathrm{Ga}$, Ge, As, Se, Br, Rb, Sr, Y, Zr, Nb, Mo, Ag, Cd, Sn, Sb, Te, Cs, Ba, La, $\mathrm{Ce}, \mathrm{Pr}, \mathrm{Nd}, \mathrm{Sm}, \mathrm{Eu}, \mathrm{Gd}, \mathrm{Tb}, \mathrm{Dy}, \mathrm{Ho}, \mathrm{Er}, \mathrm{Tm}, \mathrm{Yb}, \mathrm{Lu}, \mathrm{Hf}, \mathrm{Ta}, \mathrm{W}, \mathrm{Pb}, \mathrm{Bi}, \mathrm{Th}$, and U) concentrations were determined in all samples by inductively coupled plasma - optical emission spectrometry (ICP-OES) and inductively coupled plasma-mass spectrometry (ICPMS). A PERKIN ELMER OPTIMA 3200RL with a PERKIN ELMER Autosampler AS-90+ was used for the ICP-OES analyses, while a PERKIN ELMER SCIEX ELAN 6000 with a PERKIN ELMER AS-91 automatic sampler was used for the ICP-MS analyses.

\section{RESULTS AND DISCUSSION}

The major and trace element concentrations for the seven samples of the present study are shown in Table 1. Calcium shows high values for all samples, since the feed lignite of Agios Dimitrios is characterized by high $\mathrm{Ca}$ contents $[1,2,6]$. The mineralogical analysis of the investigated samples showed that calcium minerals are dominant (anhydrite, calcite, portlandite, lime, high-calcium glass) [6]. On the other hand, very low concentrations for Al and $\mathrm{Si}$ are noticed, in agreement with the characterization of the Agios Dimitrios fly ashes as C-Class fly ash $[4,10]$. Other elements that have relatively high concentration values, in almost all samples, are S, Ti, Cr, Mn, Ni, Zn, and $\mathrm{Sr}$.

Some differences in the chemical composition of the samples between the slagging and the fouling zones are observed. The chemical composition of the samples collected from the latter show a more constant composition than those from the slagging zone. Only three elements ( $\mathrm{Ti}, \mathrm{Cr}$, and $\mathrm{Mn}$ ) have a noticeable variation in their concentrations for this zone.

On the other hand, the elements showing high variation in the slagging zone are $\mathrm{Al}, \mathrm{Fe}$, $\mathrm{Na}, \mathrm{S}, \mathrm{Li}, \mathrm{B}, \mathrm{Ti}, \mathrm{Cr}, \mathrm{Ni}, \mathrm{As}, \mathrm{Br}, \mathrm{Cd}$, and $\mathrm{Ba}$.

This phenomenon could be related to the high temperatures $\left(800-1200{ }^{\circ} \mathrm{C}\right.$ ) and the strong turbulence existing in that part of the boiler which makes the environment relatively unstable [6]. In addition, the slag samples show higher concentrations for $\mathrm{Al}, \mathrm{Na}, \mathrm{S}, \mathrm{Li}, \mathrm{B}$, $\mathrm{Ni}, \mathrm{Br}$, and $\mathrm{Cd}$ than for the fouling samples. On the contrary, $\mathrm{Ca}, \mathrm{V}, \mathrm{Cr}, \mathrm{Mn}$, As, Sr, W, and $U$ show higher values in the fouling zone. Moreover, $W$ is found with relatively high values only in the fouling zone. It is very probable that it derives from the metal parts of the convective tubes. No noticeable differences for both zones are found for the rest of the elements. 
Table 1. Major (in $\mathrm{g} \mathrm{kg}^{-1}$ ) and trace elements (in $\mathrm{mg} \mathrm{kg}^{-1}$ ) concentrations of the samples of the present study (LD: limit of detection, ND: not determined)

\begin{tabular}{|c|c|c|c|c|c|c|c|}
\hline & slaggir & g zone & & uling zor & & bottom ash & fly ash \\
\hline element & GP-1 & GP-4 & GP-3 & GP-5 & GP-6 & GP-7 & GP-2 \\
\hline $\mathrm{Al}$ & 15.5 & 58.3 & 20.0 & 24.3 & 20.9 & 39.2 & 46.6 \\
\hline $\mathbf{P}$ & 1.1 & 1.4 & 1.4 & 1.3 & 1.4 & 0.7 & 1.4 \\
\hline $\mathrm{Ca}$ & 234.9 & 204.1 & 308.4 & 321.5 & 327.7 & 78.7 & 267.3 \\
\hline Mg & 12.9 & 19.5 & 25.6 & 20.4 & 22.3 & 12.0 & 21.4 \\
\hline $\mathbf{K}$ & 1.0 & 3.7 & 1.0 & 1.7 & 1.6 & 3.8 & 5.7 \\
\hline $\mathrm{Fe}$ & 80.7 & 34.8 & 32.6 & 29.7 & 32.1 & 19.8 & 36.7 \\
\hline $\mathrm{Na}$ & $<$ LD & 0.9 & $<$ LD & $<$ LD & $<$ LD & 3.2 & 0.7 \\
\hline Si & ND & ND & ND & ND & ND & ND & ND \\
\hline $\mathbf{S}$ & 148.8 & 11.6 & 83.0 & 59.1 & 67.8 & 6.2 & 33.7 \\
\hline $\mathrm{Cl}$ & 0.4 & 0.4 & 0.4 & 0.4 & 0.3 & 1.7 & 0.4 \\
\hline Li & 6.3 & 33.5 & 11.7 & 16.3 & 11.8 & 29.8 & 28.7 \\
\hline $\mathrm{Be}$ & 0.6 & 1.9 & 1.1 & 1.1 & 1.0 & 1.2 & 1.6 \\
\hline B & $<L D$ & 0.6 & 2.7 & 1.6 & 4.4 & 2.7 & $<$ LD \\
\hline $\mathrm{Ti}$ & 1058.5 & 3342.4 & 1749.0 & 1765.9 & 3086.8 & 2227.1 & 2822.1 \\
\hline $\mathbf{V}$ & 103.0 & 133.1 & 198.7 & 174.4 & 167.1 & 101.0 & 133.8 \\
\hline $\mathrm{Cr}$ & 131.7 & 272.8 & 261.5 & 350.1 & 328.1 & 318.4 & 296.2 \\
\hline Mn & 325.6 & 346.3 & 338.2 & 317.8 & 1228.8 & 158.1 & 390.8 \\
\hline Co & 34.8 & 25.9 & 30.8 & 36.1 & 46.4 & 17.0 & 23.6 \\
\hline $\mathrm{Ni}$ & 1054.0 & 460.6 & 437.2 & 376.0 & 376.0 & 433.1 & 386.5 \\
\hline $\mathrm{Cu}$ & 57.5 & 40.1 & 42.8 & 37.5 & 45.0 & 28.7 & 39.0 \\
\hline $\mathrm{Zn}$ & 82.0 & 67.6 & 66.8 & 73.1 & 73.7 & 59.6 & 91.3 \\
\hline $\mathbf{G a}$ & 5.8 & 13.2 & 9.9 & 10.4 & 9.5 & 9.8 & 12.0 \\
\hline Ge & 1.0 & 1.0 & 2.1 & 1.9 & 1.8 & 0.4 & 1.0 \\
\hline As & 33.6 & 15.2 & 76.1 & 69.2 & 69.7 & 11.0 & 26.6 \\
\hline $\mathrm{Se}$ & 0.6 & 1.3 & 12.4 & 7.1 & 10.0 & $<$ LD & 3.6 \\
\hline $\mathrm{Br}$ & $<$ LD & 1.4 & 3.2 & 1.2 & 0.9 & 0.4 & 5.2 \\
\hline $\mathbf{R b}$ & 9.2 & 25.8 & 11.6 & 17.0 & 12.2 & 36.6 & 43.9 \\
\hline $\mathrm{Sr}$ & 321.8 & 314.4 & 467.2 & 430.9 & 449.9 & 153.7 & 393.4 \\
\hline $\mathbf{Y}$ & 9.2 & 16.2 & 15.6 & 14.0 & 14.7 & 10.1 & 17.3 \\
\hline $\mathrm{Zr}$ & 27.8 & 52.8 & 48.3 & 40.3 & 62.6 & 45.0 & 49.5 \\
\hline $\mathrm{Nb}$ & 5.2 & 11.3 & 8.2 & 8.0 & 11.6 & 8.3 & 10.9 \\
\hline Mo & 6.9 & 5.7 & 15.6 & 12.8 & 14.4 & 35.4 & 5.6 \\
\hline $\mathrm{Ag}$ & 2.1 & 2.8 & 2.8 & 2.7 & 2.9 & 4.0 & 3.0 \\
\hline Cd & 7.2 & 0.8 & 2.2 & 1.5 & 2.0 & 0.4 & 1.3 \\
\hline Sn & 4.4 & 3.1 & 5.1 & 4.7 & 5.0 & 265.5 & 3.6 \\
\hline Sb & 1.8 & 1.1 & 4.4 & 3.5 & 3.7 & 0.9 & 1.5 \\
\hline $\mathrm{Te}$ & 2.7 & 3.7 & 5.8 & 6.0 & 6.3 & 2.2 & 5.5 \\
\hline Cs & 0.5 & 2.2 & 1.3 & 1.7 & 1.3 & 3.1 & 3.6 \\
\hline $\mathrm{Ba}$ & 127.8 & 257.2 & 170.8 & 178.0 & 166.3 & 146.4 & 277.5 \\
\hline La & 13.4 & 27.9 & 16.6 & 17.8 & 16.4 & 17.5 & 29.1 \\
\hline
\end{tabular}


Table 1. Continued.

\begin{tabular}{|c|c|c|c|c|c|c|c|}
\hline \multirow[b]{2}{*}{ element } & \multicolumn{2}{|c|}{ slagging zone } & \multicolumn{3}{|c|}{ fouling zone } & \multirow{2}{*}{$\frac{\text { bottom ash }}{\text { GP-7 }}$} & \multirow{2}{*}{$\begin{array}{c}\text { fly ash } \\
\text { GP-2 }\end{array}$} \\
\hline & GP-1 & GP-4 & GP-3 & GP-5 & GP-6 & & \\
\hline $\mathrm{Ce}$ & 25.7 & 51.0 & 33.5 & 35.6 & 32.8 & 33.2 & 56.3 \\
\hline $\operatorname{Pr}$ & 3.0 & 6.2 & 4.1 & 4.3 & 4.0 & 4.0 & 6.7 \\
\hline Nd & 10.9 & 22.5 & 15.9 & 16.2 & 15.2 & 14.5 & 24.6 \\
\hline $\mathrm{Sm}$ & 2.2 & 4.2 & 3.3 & 3.3 & 3.0 & 2.7 & 4.8 \\
\hline $\mathrm{Eu}$ & 0.5 & 1.0 & 0.8 & 0.7 & 0.7 & 0.6 & 1.0 \\
\hline Gd & 2.1 & 4.1 & 3.3 & 3.1 & 3.0 & 3.2 & 4.3 \\
\hline Tb & 0.3 & 0.6 & 0.5 & 0.5 & 0.5 & 0.4 & 0.6 \\
\hline Dy & 1.7 & 3.2 & 2.8 & 2.6 & 2.6 & 2.0 & 3.4 \\
\hline Ho & 0.3 & 0.6 & 0.6 & 0.5 & 0.5 & 0.4 & 0.6 \\
\hline $\mathrm{Er}$ & 0.9 & 1.8 & 1.6 & 1.5 & 1.5 & 1.1 & 1.8 \\
\hline $\mathrm{Tm}$ & 0.1 & 0.3 & 0.2 & 0.2 & 0.2 & 0.2 & 0.3 \\
\hline $\mathrm{Yb}$ & 0.9 & 1.6 & 1.5 & 1.4 & 1.4 & 1.1 & 1.7 \\
\hline Lu & 0.1 & 0.3 & 0.2 & 0.2 & 0.2 & 0.2 & 0.2 \\
\hline $\mathrm{Hf}$ & 0.8 & 1.6 & 1.4 & 1.3 & 1.9 & 1.4 & 1.5 \\
\hline $\mathrm{Ta}$ & 0.3 & 0.3 & 0.5 & 0.5 & 0.5 & 0.5 & 0.2 \\
\hline $\mathbf{w}$ & 14.4 & 4.9 & 69.9 & 72.1 & 69.2 & 4.3 & 3.0 \\
\hline $\mathrm{Pb}$ & 11.5 & 23.1 & 16.0 & 16.8 & 15.4 & 13.2 & 30.7 \\
\hline $\mathrm{Bi}$ & 0.3 & 0.2 & 0.6 & 0.5 & 0.6 & 0.1 & 0.5 \\
\hline Th & 4.7 & 9.5 & 6.9 & 6.8 & 6.6 & 6.1 & 10.4 \\
\hline $\mathbf{U}$ & 12.9 & 18.9 & 38.0 & 31.6 & 31.0 & 11.4 & 23.4 \\
\hline
\end{tabular}

The majority of the elements show almost the same concentration for both fly ash and bottom ash samples. Sodium, $\mathrm{Cl}, \mathrm{B}, \mathrm{Mo}$, and $\mathrm{Sn}$ are enriched in the bottom ash sample, while $\mathrm{Ca}, \mathrm{S}, \mathrm{Ti}, \mathrm{Mn}, \mathrm{Zn}, \mathrm{As}, \mathrm{Se}, \mathrm{Br}, \mathrm{Sr}, \mathrm{Cd}, \mathrm{Ba}, \mathrm{Pb}$, and $\mathrm{U}$ are enriched in the fly ash sample. The enrichment of few elements in the bottom ash sample is probably related to the high unburned lignite content of this sample (up to 48\%) [9]. This fact demonstrates that these elements have a behavior more volatile during and after combustion. On the contrary, the elements showing high concentration values in the fly ash sample probably have an inorganic affinity. From an environmental point of view this conclusion is very important since the majority of these elements are of environmental concern (As, Se, Cd, $\mathrm{Pb}, \mathrm{U}, \mathrm{S}, \mathrm{Zn}$, and $\mathrm{Mn}$ ). The rest of the elements show no clear preference towards volatile or non-volatile behavior of the ashes produced after combustion in the power unit. Furthermore, the chemical composition of the bottom ash and the fly ash, in general, seems to be similar to the slag and fouling samples. However, for each sample, some important differences are encountered. Bottom ash has lower concentrations for $\mathrm{Ca}, \mathrm{Mn}$, $\mathrm{Zn}$, and $\mathrm{Sr}$, while fly ash has lower concentration for $\mathrm{Ni}$ and higher concentrations for $\mathrm{Ti}$, $\mathrm{Zn}, \mathrm{Ba}$, and $\mathrm{Pb}$.

\section{CONCLUSIONS}

Calcium is the most abundant element in all samples of the present study, related to the high calcium mineral content of the fly ash. The samples collected from the slagging zone show a larger variation in their chemical composition than those collected inside the fouling zone. Aluminum, $\mathrm{Na}, \mathrm{S}, \mathrm{Li}, \mathrm{B}, \mathrm{Ni}, \mathrm{Br}$, and $\mathrm{Cd}$ have higher concentrations for the slags while $\mathrm{Ca}, \mathrm{V}, \mathrm{Cr}, \mathrm{Mn}, \mathrm{As}, \mathrm{Sr}, \mathrm{W}$, and $\mathrm{U}$ show higher values for the fouling zone samples. Despite some differences in their chemical composition, the bottom ash and the fly ash have similar elemental concentrations to those of the slag and fouling zone 
samples. Sodium, $\mathrm{Cl}, \mathrm{B}, \mathrm{Mo}$, and $\mathrm{Sn}$ show a more volatile behavior, probably because of their organic affinity, while $\mathrm{Ca}, \mathrm{S}, \mathrm{Ti}, \mathrm{Mn}, \mathrm{Zn}, \mathrm{As}, \mathrm{Se}, \mathrm{Br}, \mathrm{Sr}, \mathrm{Cd}, \mathrm{Ba}, \mathrm{Pb}$, and $\mathrm{U}$ show a less volatile behavior, probably related to their inorganic affinity which reveals their association with the different phases that constitute the fly ash. Major and trace element concentrations of the feed lignite as well as the intermediate sterile materials, coexcavated with lignite, are responsible for the chemical composition of the combustion by-products.

\section{REFERENCES}

1. Sotiropoulos D., Georgakopoulos A. and Kolovos N. (2005) Impact of free-calcium oxide content of the fly ash on dust and sulfur dioxide emissions in a lignite-fired Power Plant, J. Air Waste Manage. (in Press).

2. Kolovos N., Georgakopoulos A., Filippidis A. and Kavouridis C. (2002) Utilization of lignite Reserves and Simultaneous Improvement of Dust Emissions and Operation Efficiency of a Power Plant by Controlling the Calcium (Total and Free) Content of the Fed Lignite. Application on the Agios Dimitrios Power Plant, Ptolemais, Greece, Energ. Fuel., 16, 15161522

3. Georgakopoulos A. (2003) Chemistry and morphology of fly ashes from the main lignite power stations of Northern Greece, Proceedings of the $8^{\text {th }}$ International Conference on Environmental Science and Technology, 8-10 September 2003, Lemnos, Greece, University of the Aegean, 256-263.

4. Georgakopoulos A. Filippidis A., Kassoli-Fournaraki A., Iordanidis A., Fernández-Turiel J.L., Llorens J.F. and Gimeno D. (2002) Environmentally important elements in fly ashes and their leachates of the Power Stations of Greece, Energ. Source., 24(1), 83-91.

5. Georgakopoulos A., Filippidis A., Kassoli-Fournaraki A., Fernández-Turiel J.L., Llorens J.F. and Mousty F. (2002) Leachability of major and trace elements of fly ash from Ptolemais Power Station, Northern Greece, Energ. Source., 24(2): 93-103.

6. Fernández -Turiel J.L., Georgakopoulos A., Gimeno D., Papastergios G. and Kolovos N. (2004) Ash Deposition in a Pulverized Coal-Fired Power Plant after High-Calcium Lignite Combustion, Energ. Fuel., 18, 1512-1518.

7. Unsworth J.F., Barrat D.J. and Roberts P.T. (1991) Coal quality and combustion performance, an international perspective, Coal Science and Technology 19, Elsevier, London, 638p.

8. Berkowitz N. (1994) An introduction to coal technology, $2^{\text {nd }}$ ed., Academic Press, Inc., N.Y., 398pp.

9. Kantiranis N., Georgakopoulos A., Filippidis A. and Drakoulis A. (2004) Mineralogy and organic matter content of bottom ash samples from Agios Dimitrios power plant, Greece, Bulletin of the Geological Society of Greece vol. XXXVI, 2004, Proceedings of the 10th International Congress, Thessaloniki, April 2004, 7p.

10. Suloway J. J., Roy W. R., Skelly T. M., Dickerson T. R., Schuller R. M. and Griffin R. A. (1983) Chemical and toxicological properties of coal fly ash. Environ. Geol. Notes, 105, 1-70. 